J. Asiat. Soc. Bangladesh, Sci. 44(2): 185-193, December 2018

\title{
LENGTH-WEIGHT RELATIONSHIP AND SEX RATIO OF AMBLYPHARYNGODON MOLA IN DEKAR HAOR OF SUNAMGANJ, BANGLADESH
}

\author{
P.R. DAS ${ }^{1}$, M.S. UDDIN ${ }^{1}$, M.S. ISLAM ${ }^{2} *$, M. BISWAS ${ }^{2}$ AND M.R. MIA ${ }^{1}$ \\ ${ }^{I}$ Department of Aquaculture, Sylhet Agricultural University, Sylhet, Bangladesh \\ ${ }^{2}$ Department of Coastal and Marine Fisheries, Sylhet Agricultural University, \\ Sylhet, Bangladesh
}

\begin{abstract}
The study was carried out to determine length-weight relationship and sex ratio of a freshwater fish Amblypharyngodon mola (Hamilton 1822) collected from Dekar haor of Sunamganj district during the period of January to August 2017. A total of 2000 fishes were collected for the study and categorized these fishes into three groups namely males, females and combined sexes. Among 2000 mola 777 were male and 1223 were female. Length-weight equations and the correlation coefficients obtained for males, females and combined ones were: males $\mathrm{Y}=-1.97+3.00 \mathrm{X}, \mathrm{r}=0.883$; females $\mathrm{Y}=-2.30+3.41 \mathrm{X}$, $\mathrm{r}=0.914$ and combined $\mathrm{Y}=-2.11+3.16 \mathrm{X}, \mathrm{r}=0.904$. Female's A. mola attained more weight with the increases in length. Value of correlation coefficient ' $r$ ' was 0.883 for male and exhibited highly positive correlation between length and weight. On the contrary, ' $r$ ' value for female was 0.914 and it had also strongly positive correlation between length and weight relationships. Length-weight relationship of A. mola for male, female and combined sexes showed allometric pattern of growth. Condition factor ' $\mathrm{K}$ ' for male, female and combined sexes was 1.09, 1.05 and 1.06, respectively and indicated better condition of fishes. The highest sex ratio (1:2.05) was found in May and the lowest $(1: 1.33)$ was in February. Dominance of females over males throughout the year was observed with an average ratio of male and female $1: 1.57$. Therefore, results of the study indicate that the existing hydrobiological conditions of the haor are conducive for food availability, free movement, feeding and better growth of the fish.
\end{abstract}

Key words: Correlation coefficient, Condition factor, Sex ratio, Haor

\section{Introduction}

Amblypharyngodon mola (Hamilton 1822) is one of the most abundant and nutritious fish species found all the year round in Dekar haor (depressed low land with seasonal and perennial waterbodies connected with canals and rivers). It is commonly known as 'Indian carplet' or 'pale carplet' and widely distributed in freshwater habitats like ponds, streams, rivers, flood plain wetlands, canal and paddy fields. Though A. mola is a small indigenous species (SIS), it has tremendous importance due to its high content of vitamin-A. The studies on its nutritive value revealed that $A$. mola contains $>2680$ retinol

*Author for correspondence: E-mail: islamms2011@yahoo.com 
activity equivalents per $100 \mathrm{~g}$ of raw and edible portions (Roos 2001). It is also rich in $\mathrm{Fe}, \mathrm{Zn}$ and $\mathrm{Ca}$ (Roos et al. 2007). This fish is relished by the common man of the region in fresh, smoked, dried as well as pickle form. In different parts of Bangladesh, it is locally known as mourala, mola, mowa or mowka. This fish is distributed in India, Bangladesh, Pakistan and Myanmar (Talwar and Jhingran 1991). Earlier the fish was considered as weed fish but in advent of time the fish is now highly demandable, economically valuable and costly fish in the market. Considering nutritious value, taste, income source, availability, family chosen fish and to alleviate poverty recently emphasis is given to culture small indigenous fish in Bangladesh, out of which mola is one of them (ARG 1986). Recently, it has also got its entry in ornamental fish trade and has been reported to be available in ornamental fish markets with moderate demand and availability. Mola (A. mola) is a self-recruiting species and its culture is being encouraged among the farmers in national economy of Bangladesh to overcome the nutritional deficiency (Gupta and Banerjee 2012).

Morphometric relationships between length and weight can be used to assess the wellbeing of individuals and to determine possible differences between separate unit stocks of the same species (King 2007). In addition, length-length relationships are also important in fisheries management for comparative growth studies (Moutopoulos and Stergiou 2002).

Condition factor is one of the standard practices in fisheries, which is used as an indicator of the variability to attribute growth coefficient. It expresses the condition of a fish such as degree of well-being, relative robustness, plumpness or fatness in numerical terms. The condition of a fish reflects recent physical and biological circumstances and fluctuates by interactions among feeding condition, parasitic infections and physical factors (Le Cren 1951). It is strongly influenced by both biotic and abiotic environmental conditions and can be used as an index to assess the status of the aquatic ecosystem in which fish lives. Condition factor also gives information, when comparing two populations living in certain feeding, density, climate and other conditions, the period of gonadal maturation and when following up the degree of feeding activity of a species to verify as to whether it is making good use of its feeding source (Anene 2005).

According to Pantulu (1961), sex ratio is an indicator of population behavior and fecundity. An understanding of the sex ratio of a fish in different months and seasons is essential for obtaining information on different segregation of the sexes and also their differential growth. To the best of the knowledge, information on length-weight relationship and sex ratio of A. mola in haor environment are not available in 
Bangladesh. Considering these, the study was undertaken with the aim to determine length-weight relationship and sex ratio of male, female and combined of A. mola from Dekar haor of Sunamganj district, Bangladesh.

\section{Materials and Methods}

The study was conducted in Dekar haor of Dakshin Sunamganj, which lies between latitude $24^{\circ} 46^{\prime} \mathrm{N}$ and $24^{\circ} 57^{\prime} \mathrm{N}$ and longitude $91^{\circ} 20^{\prime} \mathrm{E}$ and $91^{\circ} 31^{\prime} \mathrm{E}$. Sample collection was done during eight months from January to August 2017. Samples were collected twice in a month at 15-day intervals.

A total of 2000 samples were collected randomly. After collection, the samples were transported to the laboratory in a large polyethylene bag with 5\% formalin. Then washed and transferred to a filter paper to remove excess water from the body surfaces of fishes.

Standard length of fish was measured from tip of the snout to base of the caudal end using measuring scale $(\mathrm{cm})$ and weight up to $0.1 \mathrm{~g}$ using digital weighing balance, respectively. Statistical relationship between length and weight was established by the parabolic equation given by Froese (2006), $\mathrm{W}=\mathrm{aL}^{\mathrm{b}}$, where, $\mathrm{W}=$ Weight of fish $(\mathrm{g}), \mathrm{L}=$ Length of fish $(\mathrm{cm}), \mathrm{a}=$ Constant and $\mathrm{b}=$ A regression coefficient expressing relationship between length and weight. The relationship $\left(\mathrm{W}=\mathrm{aL}^{\mathrm{b}}\right.$ ) was converted into logarithmic form of equation giving a straight line relationship graphically, $\log W=\log a+b \log$ $\mathrm{L}$. The equation is same to $\mathrm{Y}=\mathrm{a}+\mathrm{bX}$, where, $\log \mathrm{W}=$ dependent variable $(\mathrm{Y}), \log \mathrm{L}=$ independent variable $(\mathrm{X}), \mathrm{b}=$ regression coefficient or slope, $\mathrm{a}=$ intercept.

Condition factor ' $\mathrm{K}$ ' was calculated by Fulton's (1904) equation, $\mathrm{K}=\mathrm{W} \times 100 / \mathrm{L}^{3 \text {, where, }}$ $\mathrm{K}=$ Condition factor, $\mathrm{W}=$ Observed body weight $(\mathrm{g}), \mathrm{L}=$ Observed length of fish $(\mathrm{cm})$.

Sex determination was done by secondary (external) sexual characteristics of fishes. Normally female fish is larger than male and male is brighter than female. In matured female, abdomen is soft and swollen, pelvic fins are smooth and caudal fin is deeply forked in spawning season and their distended abdomen is easily visible. For determination of sex ratio, a total of 2000 fishes were used and ratio was analyzed by $\chi^{2}$ test.

$$
\chi^{2}=\frac{\sum(\mathrm{O}-\mathrm{E})^{2}}{\mathrm{E}}
$$

where, $\mathrm{O}=$ Observed value and $\mathrm{E}=$ Expected value.

Data were analyzed using Microsoft Office Excel and SPSS software (Version 20) with $\mathrm{p}<0.05$ considered significantly different. 


\section{Results and Discussion}

Higher degree of correlation between length and weight was indicated by correlation coefficient ' $r$ '. The observed length and weight relationship of male, female and combined are presented in scatter diagrams (Figs 1 - 3). Values of regression coefficient computed were $3.00,3.41$ and 3.16 , respectively for male, female and combined sexes.

Table 1. Length-weight relationship and condition factor of male, female and combined Amblypharyngodon mola.

\begin{tabular}{lccccc}
\hline Sex & $\begin{array}{c}\text { No. of } \\
\text { sample }\end{array}$ & $\begin{array}{c}\text { Value } \\
\text { of ' } \mathrm{b} \text { ' }\end{array}$ & $\begin{array}{c}\text { Logarithmic } \\
\text { equation }\end{array}$ & $\begin{array}{c}\text { Correlation } \\
\text { coefficient ' } \mathrm{r} \text { ' }\end{array}$ & $\begin{array}{c}\text { Condition } \\
\text { factor 'k' }\end{array}$ \\
\hline Male & 777 & 3.00 & $\mathrm{Y}=-1.97+3.00 \mathrm{X}$ & 0.883 & 1.090 \\
Female & 1223 & 3.41 & $\mathrm{Y}=-2.30+3.41 \mathrm{X}$ & 0.914 & 1.052 \\
Combined & 2000 & 3.16 & $\mathrm{Y}=-2.11+3.16 \mathrm{X}$ & 0.904 & 1.066 \\
\hline
\end{tabular}

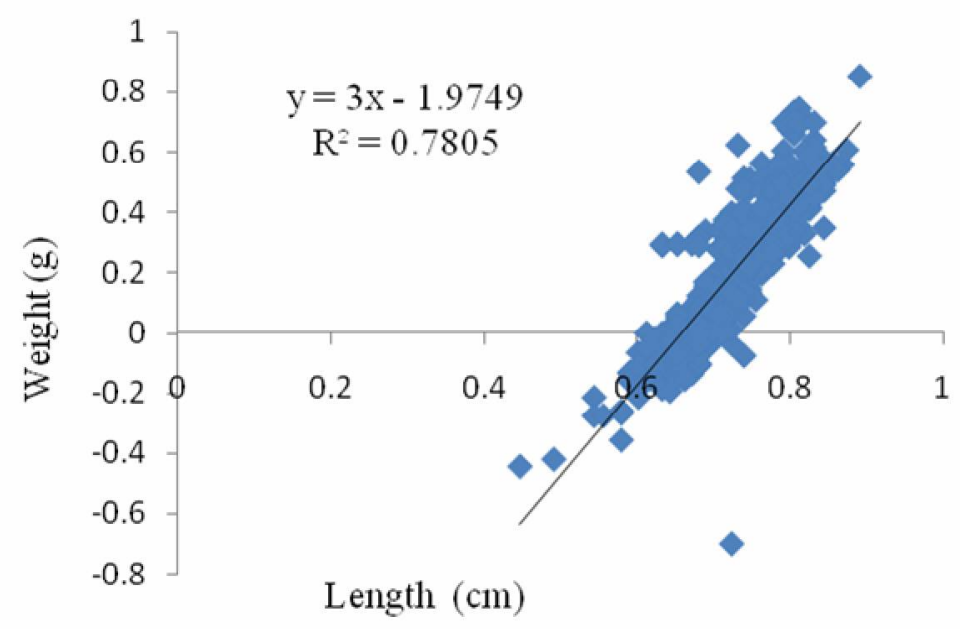

Fig. 1. Length-weight relationship of male A. mola.

Correlation coefficient ' $r$ ': Values of correlation coefficient ' $r$ ' for both male and female were 0.883 and 0.914 , respectively and showed strongly positive and significant relationships between length and weight (Table 1 and Figs 1 - 2). Combined population also exhibited strongly positive correlation and showed ' $r$ ' value as 0.904 , which is closed to 1 (Table 1 and Fig. 3). Findings of the study reveal that the growth performance of both male and female A. mola are higher owing to correlation coefficient ' $r$ ' exhibits high degree of positive allometric correlation between the length and weight relationship 
of A. mola (Table 1). Positive allometric growth might be due to higher proficiency in feeding and better environmental condition for survival of the species (Soni and Kathal 1953, Saikia et al. 2011). Gohain and Goswami (2013) and Deka and Bura (2015) also reported the effect of availability of food and other associated factors to be responsible for positive allometric growth.

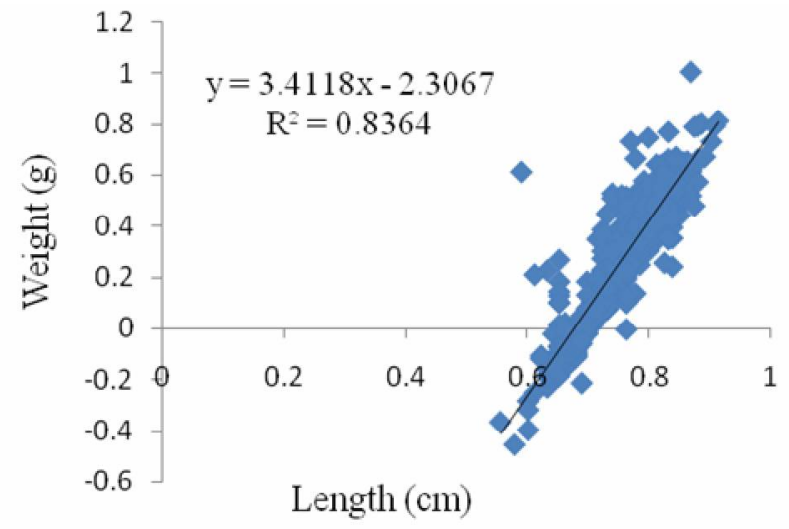

Fig. 2. Length-weight relationship of female A. mola.

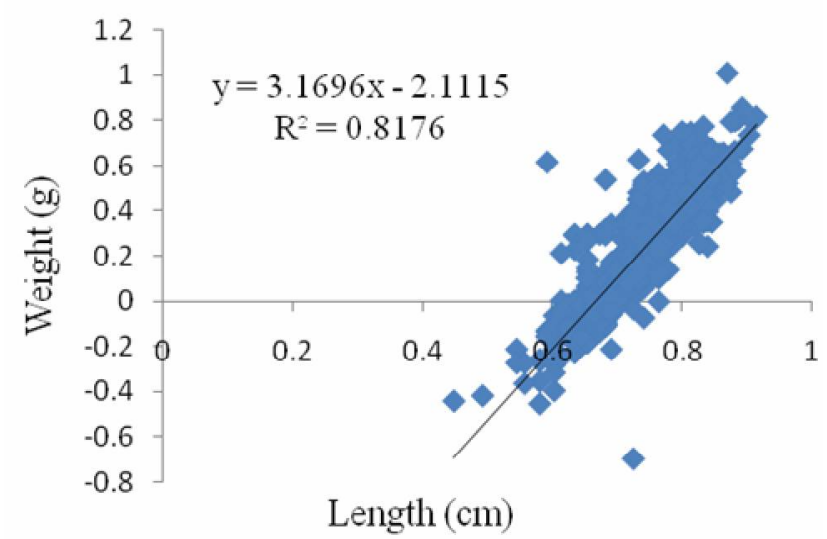

Fig. 3. Length-weight relationship of combined A. mola.

Regression coefficient value ' $b$ ': Regression coefficient ' $b$ ' is an indicator of isometric/allometric pattern of fish growth. In the present study, value of ' $b$ ' was 3.00 for male, which indicated isometric pattern of growth in ideal condition and 3.41 for female, which indicated positive allometric pattern of growth (Table 1 and Figs 1 - 2). 'b' value of combined sexes was 3.16, which also indicated positive allometric growth (Table 1 and Fig. 3). 
In all cases the values of ' $b$ ' are not found in normal ranges between 2.5 and 4.0. Findings of the study also indicate that ' $b$ ' value follows the 'Cube law' strictly for male as it remains constant at 3.0 for an ideal fish and deviates from female in a particular environmental condition. Several biological factors like sex, size of fish, physiological condition and gonadal maturity, feeding and fatness have significant influence over length-weight relationship of fishes (Le Cren 1951, Devaraj 1973, Reddy and Rao 1992). Regression value of female and male of the present study is more or less similar to the findings of Mitra et al. (2005), Kumar et al. (2006), Prasad and Ali (2007) and Baishya et al. (2010) who worked on Puntius sophore, Labeo bata, Rasbora daniconius and Amblypharyngodon mola, respectively in India and Bangladesh. Higher regression value of female fish may be attributed to the general condition of appetite, gonadal contents of fish and also environmental conditions.

Condition factor ' $K$ ': Values of condition factor ' $\mathrm{K}$ ' for male, female and combined sexes were 1.090, 1.052 and 1.066, respectively and it was higher than the value of 1 , which indicate good condition of the fishes (Table 1 and Figs 1 - 3). It was observed that males indicated slightly better condition than females, which might be associated with food proficiency, physiological or other better environmental factors of the waterbody.

Fish with higher value of ' $\mathrm{K}$ ' are heavy for its length, while with low ' $\mathrm{K}$ ' are lighter (Bagenal and Tesch 1978). ' $\mathrm{K}$ ' value greater than 1 indicates better condition of fish (Le Cren 1951). These findings are in agreement with the findings of the present study.

Sex ratio: Data on sex ratio of $A$. mola revealed that number of females was more than that of males. Per cent of individual month and total percentage of male and female showed females were dominated in natural population throughout the year (Table 2). Out of 2000 fishes, 777 were males and 1223 females. Monthly sex ratio between males and females ranged from $1: 1.33$ to $1: 2.05$ and average was $1: 1.57\left(\chi^{2}=68.34, \mathrm{p}<0.05, \mathrm{~N}\right.$ $=2000)$. The highest sex ratio was obtained $1: 2.05$ in May, which are not coincided with the result of Gogoi and Goswami (2014) who reported the highest sex ratio of male and female as $1: 3.61$ in July. These may be occurred due to location, food availability and environmental factors.

Dominance of females over the males in freshwater fish A. mola was also reported by Azadi and Mamun (2004) as well as Afroze et al. (1991-92). Dominance of females was also seen in other species of fishes like E. vacha. Different populations inhabit in different regions and show different sex ratios. Higher sex ratio was found during first breeding season and lower sex ratio in second breeding when water parameters are at their peak as reported by Singh (1994). A rising temperature and moderate water 
velocity, vulnerability of females to their predators and other natural hazards, migratory phase in brood population are some of the reasons for changes in sex ratio in fishes (Gogoi and Goswami 2014).

Table 2. Monthly distribution of sex ratio and Chi-square $\left(\chi^{2}\right)$ value of Amblypharyngodon mola.

\begin{tabular}{|c|c|c|c|c|c|c|c|c|c|}
\hline \multirow{2}{*}{ Month } & \multicolumn{2}{|c|}{ Male } & \multicolumn{2}{|c|}{ Female } & \multicolumn{2}{|c|}{ Combine } & \multirow{2}{*}{$\begin{array}{l}\text { Ratio of male } \\
\text { \& female }\end{array}$} & \multirow{2}{*}{$\begin{array}{c}\text { Chi } \\
\text { value }\end{array}$} & \multirow{2}{*}{$\begin{array}{c}\mathrm{p} \\
\text { value }\end{array}$} \\
\hline & Count & $\%$ & Count & $\%$ & Count & $\%$ & & & \\
\hline January & 102 & 42.7 & 137 & 57.3 & 239 & 100.0 & $1.00: 1.34$ & 50.25 & $<0.05$ \\
\hline February & 112 & 42.9 & 149 & 57.1 & 261 & 100.0 & $1.00: 1.33$ & 18.665 & $<0.05$ \\
\hline March & 106 & 40.2 & 158 & 59.8 & 264 & 100.0 & $1.00: 1.49$ & 63.24 & $<0.05$ \\
\hline April & 90 & 38.1 & 146 & 61.9 & 236 & 100.0 & $1.00: 1.62$ & 52.95 & $<0.05$ \\
\hline May & 81 & 32.8 & 166 & 67.2 & 247 & 100.0 & $1.00: 2.05$ & 102.23 & $<0.05$ \\
\hline June & 95 & 37.5 & 158 & 62.5 & 253 & 100.0 & $1.00: 1.66$ & 74.14 & $<0.05$ \\
\hline July & 99 & 40.6 & 145 & 59.4 & 244 & 100.0 & $1.00: 1.46$ & 44.25 & $<0.05$ \\
\hline August & 92 & 35.9 & 164 & 64.1 & 256 & 100.0 & $1.00: 1.78$ & 72.25 & $<0.05$ \\
\hline Total & 777 & 38.8 & 1223 & 61.2 & 2000 & 100.0 & $1.00: 1.57$ & 68.34 & $<0.05$ \\
\hline
\end{tabular}

Findings of the study imply that females of $A$. mola are more healthy and haviour with increases in length than males. Length-weight relationship of A. mola in male, female and combined sexes shows positive allometric pattern of growth of the fishes. So it can be concluded that existing hydrobiological conditions of the haor is conducive for feeding, free movement and better growth of the fishes. Results of the study also indicate that most of the fishes are females during breeding season, whereas numbers of males are close to female fishes during nonbreeding seasons but not above.

\section{Acknowledgements}

Authors are indebted to Krishi Gobeshona Foundation (KGF), BARC, Farmgate, Dhaka for providing financial support to perform the research.

\section{References}

Afroze, S., M.A. Hossain and S. Parween. 1991-92. Notes on the size frequency distribution and length-weight relationship of freshwater fish Amblypharyngodon mola (Hamilton). Univ. J. Zool. Rajshahi Univ. 10 \&11: 103-104 pp.

Anene, A. 2005. Condition factor of four Cichlid species of a man-made lake in Imo State, Southeastern Nigeria. Turk. J. Fish. \& Aqua Sci. 5: 43-47.

ARG (Aquatic Research Group). 1986. Hydrobiology of the Kaptai reservoir. FAO/UNDP research project contact No. DP/79/015-4/F1. Final Report, 192 pp. 
Azadi, M.A. and A. Mamun. 2004. Reproductive biology of the cyprinid Amblypharyngodon mola (Hamilton) from the Kaptai reservoir, Bangladesh. Paki. J. Bio. Sci. 7(10): 1727-1729.

Baishya, A., A. Dutta and S. Bordoloi. 2010. Morphometry and length-weight relationship of Amblypharyngodon mola (Hamilton-Buchanan, 1822). Indian J. Fish. 57(1): 87-91.

Begenal, T.B. and A.T. Tesch. 1978. Conditions and growth pattern in fresh water habitats. Blackwell Scientific Publications, Oxford. 75-89 pp.

Deka, P. and G.A. Bura. 2015. Length-weight relationship and relative condition factor of Rita rita (Hamilton, 1822), Pangasius pangasius (Hamilton, 1822) and Chitala chitala (Hamilton, 1822) of Brahmaputra river system of Assam, India. Inter. J. Fish. and Aqua. Stud. 3(1): $162-164$

Devaraj, M. 1973. Biology of the large snakehead Ophiocephalus marulius (Ham) in Bhavanisagar waters. Indian J. Fish. 20(2): 280-307.

Froese, R. 2006. Cube law, condition factor, and weight-length relationship: History, meta-analysis and recommendations. J. Appl. Ichthyol. 22(4): 241-253.

Fulton, T.W. 1904. The rate of growth of fishes.Twenty-second annual report, part III. Fisheries board of Scotland, Edinburgh. 141-241 pp.

Gogoi, R and U.C. Goswami. 2014. Length-weight relationship and sex ratio of fresh water fish Amblypharyngodon mola (Ham.-Buch) from Assam. Inter. J. Fish. and Aqua. Stud. 1(4): 68-71.

Gohain, A.B. and M.M. Goswami. 2013. A study on length-weight relationship and condition factor in different age groups of Clarias brachus (Hamilton, 1882) in wetland aqua habitat of Assam. India. J. Aqua. 14(1-2): 65-70.

Gupta, S. and S. Banerjee. 2012. Indigenous ornamental fish: A new boon in ornamental fish trade of West Bengal. Fishing Chim. 32(1): 130-134.

King, M. 2007. Fisheries biology, assessment and management. 2nd edn. Blackwell Sci. Publ, Oxford. 43-48 pp.

Kumar, H.K., B.R. Kiran, R. Purushotham, E.T. Puttaiah and S. Manjappa. 2006. Length-weight relationship of cyprinid fish Rasbora daniconius (Hamilton-Buchanan) from Sharavathi reservoir, Karnataka. Zoos' Print J. 21(1): 2140-2141.

Le Cren, E.D. 1951. Length-weight relationship and seasonal cycle in gonadal weight and condition in the perch (Perca fluviatilis). J. Anim. Ecol. 20: 201-219.

Mitra, K., V.R. Suresh, G.K. Vinci and B. Naskar. 2005. Length-weight relation, reproductive characters and condition of Puntius sophore (Hamilton) from a flood plain wetland in West Bengal. J. Inland Fish. Soc. India. 37(1): 16-22.

Moutopoulos, D.K. and K.I. Stergiou. 2002. Length-weight and length-length relationship of fish species from the Aegean sea (Greece). J. Appl. Ichthyol. 18(3): 200-203.

Pantulu, V.R. 1961. Determination of age and growth of Mystus gulio by the use of pectoral spines with observations on its biology and fishery in Hoogly estuary. Proceedings of the National Institute of Science of India. 27(4): 198-225.

Prasad, G. and A.P.H. Ali. 2007. Length-weight relationship of a cyprinid fish Puntius filamentosus from Chalakudy River, Kerala. Zoos. Print. J. 22(3): 2637-2638.

Reddy, V.S. and M.B. Rao. 1992. Length-weight relationship and relative condition of Puntius sophore (Ham-Buch) from lake Hussain Sagar, Hyderabad, India. J. Inland Fish. Soc. India. 24(1): $22-25$. 
Roos, N. 2001. Fish consumption and aquaculture in rural Bangladesh: Nutritional contribution and production potential of culturing small indigenous fish species in pond polyculture with commonly cultured Carps. Ph. D. Dissertation, Research Department of Human Nutrition, RVAU, Denmark.

Roos, N, M.A. Wahab, C. Chamnan and H. Thilsted. 2007. The role of fish in food-based strategies to combat vitamin A and mineral deficiencies in developing countries. The J. Nutri. 137(4): 1106-1109.

Saikia, A.K., A.S.K. Singh, D.N. Das and S.P. Biswas. 2011. Length-weight relationship and condition factor of spotted snakehead, Channa punctatus (Bloch), Bulletin of Life Science 17: 102-108.

Singh, S. 1994. Some aspects of fishery and biology of Labeo rohita (Ham-Buch) from Jaisamand, Rajasthan. M. Sc. (Agri.) Thesis, Rajasthan Agricultural University, Bikaner.

Soni, D.D. and M. Kathal. 1953. Length-weight relationship in Cirrhina mrigala (Val.) and Cyprinus carpio (Ham.). Matsya 5: 67-72.

Talwar, P.K. and A.G. Jhingran. 1991. Inland fishes of India and adjacent countries. Oxford and IBH Publishing Co. Pvt. Ltd. New Delhi. 1(2): 1158.

(Revised copy received on 26.10.2018) 